\title{
U-Pb Zircon Age, Geochemical and Sr-Nd Isotopic Constraints on the Age and Origin of the Granodiorites in Guilong, Southeastern Yunnan Province, Southern China
}

\author{
Shen Liu ${ }^{1}$, Ruizhong $\mathrm{Hu}^{1}$, Caixia Feng ${ }^{1}$, Shan $\mathrm{Gao}^{2}$, Guangying Feng ${ }^{1}$, Youqiang $\mathrm{Qi}^{1}$, Tao Wang ${ }^{3}$, \\ Ian M. Coulson ${ }^{4}$, Yuhong Yang ${ }^{1}$, Chaogui Yang ${ }^{1}$ \\ ${ }^{1}$ State Key Laboratory of Ore Deposit Geochemistry, Institute of Geochemistry, Chinese Academy of Sciences, Guiyang, China \\ ${ }^{2}$ State Key Laboratory of Geological Processes and Mineral Resources, China University of Geosciences, Wuhan, China \\ ${ }^{3}$ Chengdu University of Technology, Chengdu, China \\ ${ }^{4}$ Solid Earth Studies Laboratory, Department of Geology, University of Regina, Regina, Canada \\ Email: liushen@vip.gyig.ac.cn
}

Received July 9, 2012; revised August 6, 2012; accepted September 7, 2012

\begin{abstract}
Post-collision felsic rocks in Southeastern Yunnan province contain granodiorites. U-Pb zircon ages, geochemical data and Sr-Nd isotopic data for these rocks are reported in the present paper. Laser ablation inductively coupled plasma mass spectrometry U-Pb zircon analyses yielded consistent age $252.5 \pm 1.0 \mathrm{Ma}$ for one sample of the felsic rocks. The granodiorites were characterized by variational and high $\left({ }^{87} \mathrm{Sr} /{ }^{86} \mathrm{Sr}\right)$, ranging from 0.7223 to 0.7236 and very low $\varepsilon_{\mathrm{Nd}}(t)$ values from -29.1 to -30.4 . In addition, these rocks are characterized by slight Eu negative anomalies, $\mathrm{Nb}, \mathrm{Ta}, \mathrm{Ti}$ and $\mathrm{Sr}$ negative anomalies on primitive mantle normalization spider. Geochemical and isotopic characteristics suggest that these rocks were derived from an enriched crust source. The granodiorites resulted from the fractionation of potassium feldspar, plagioclase and ilmenite or rutile. However, the granodiorites were unaffected by visible crustal contamination during ascent. As a result, the granodiorites may have been formed due to partial melting of crust-derived sedimentary rocks beneath southeastern Yunnan province, southern China.
\end{abstract}

Keywords: Granodiorites; Age; Origin; Southeastern Yunnan Province; Southern China

\section{Introduction}

Felsic rocks (e.g., granite, granodiorite, etc.) are widely distributed in Honghe polymetallic deposits (super-large $\mathrm{Sn}, \mathrm{Cu}, \mathrm{Pb}, \mathrm{Zn}, \mathrm{Sb}, \mathrm{Ag}, \mathrm{Mo}, \mathrm{Au}$ and Bi deposits) [1-6] and Bainiuchang super-large Ag- $\mathrm{Pb}-\mathrm{Zn}$ polymetallic deposits [7-14]. These rocks, especially granite and granodiorite, can be used to study the mineralization and metallogenesis of polymetallic deposits in southeastern Yunnan province, Southern China.

Although a number of studies about deposits have been carried out, recent analytical techniques and systematic geochemical studies (e.g., ages, geochemical data and isotopic data) on granites and granodiorites are limited. Therefore, we provide systematic geochemical data and LA-ICP-MS zircon U-Pb and Sr-Nd data for the granodiorites to constrain age, source, fractionation and genetic model of the studied felsic rocks.

\section{Geological Setting and Petrography}

Many types of Mesozoic-Cenozoic granites and acidic porphyries are present in southeastern Yunnan province. Each felsic rock may provide important insights into the tectonothermal evolution of the Mesozoic-Cenozoic lithosphere of Yunnan province and the possible linkage(s) between Yunnan and other places (i.e., terrene, craton, etc.). Limited precise ages for the felsic rocks in Yunnan province have been published in recent papers.

The study area is located within Guilong area, Luchun County, Yunnan province, southeastern China (Figure 1). Granodiorites in Guilong are emplaced into Trias sedimentary rocks $\left(\mathbf{T}_{3} \mathbf{g}\right)$ (e.g., sandstone and shale) and granite without precise age. Some orthoclase and mafic dykes (x, lamprophyres) are present in the southern margin of the granodiorites. The granodiorites are commonly $\sim 0.9 \mathrm{~km}$ wide and $\sim 1.7 \mathrm{~km}$ long. They are exposed for ca. $1.6 \mathrm{~km}^{2}$. The ages of these rocks remain unknown. Figure 2 shows the representative photomicrographs of the granodiorites from Guilong. All granodiorites are porphyry with typical porphyritic texture and massive structure (Figure 2). The granodiorites mainly contain $40 \%$ to $45 \%$ plagioclase, $16 \%$ to $18 \%$ potash feldspar (K-feld- 


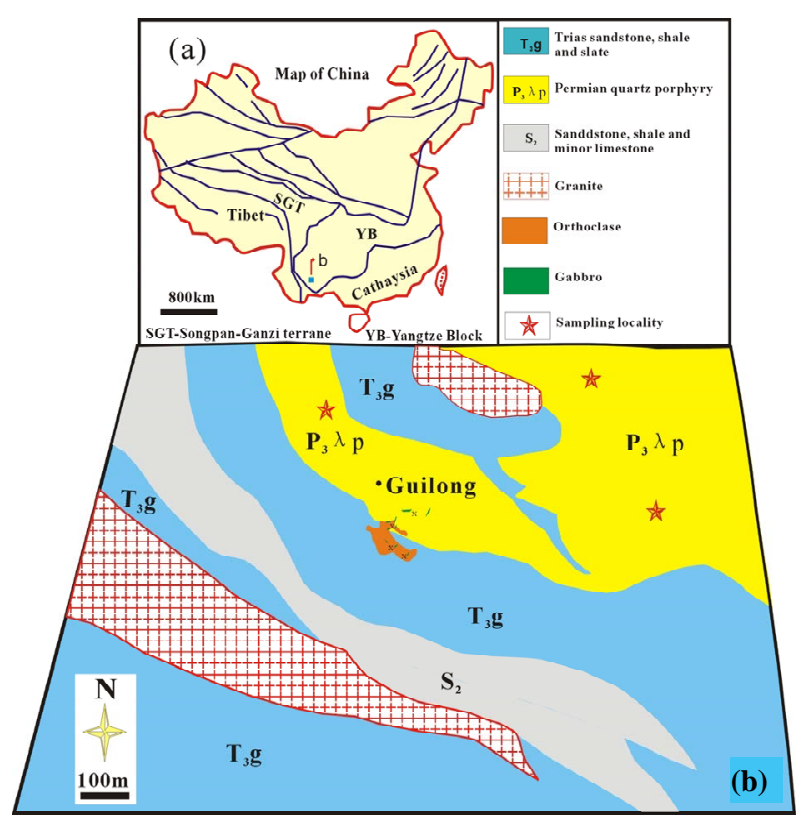

Figure 1. (a) Simplified tectonic map of the study area, Yunnan Province, China; (b) Map of China and distributions of the fault.

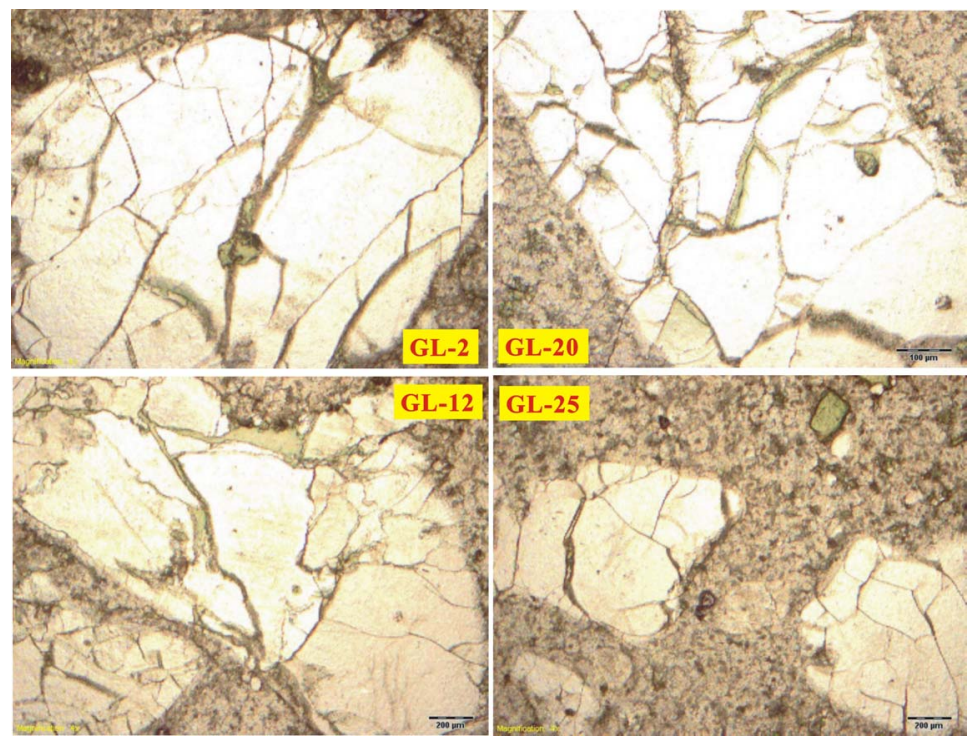

Figure 2. Repressive photos of granodiorites in Guilong, Southeastern Yunnan Province.

spar), $20 \%$ to $25 \%$ quartz, $5.0 \%$ to $8.0 \%$ biotite, $2.0 \%$ to $5.0 \%$ hornblende and minor $(<2.0 \%)$ accessory minerals, such as apatite, titanite, zircon, magnetite, allanite, etc.

\section{Analytical Procedures}

\subsection{U-Pb Dating by LA-ICP-MS Method}

Zircon was separated from one sample (GL01) using conventional heavy liquid and magnetic techniques at the Langfang Regional Geological Survey, Hebei Province, China. Zircon separates were examined under transmitted and reflected light and by cathodoluminescence petrography at the State Key Laboratory of Continental Dynamics, Northwest University, China, to observe their external and internal structures.

Laser-ablation techniques were employed for zircon age determinations (Table 1; Figure 3) using an Agilent 7500a ICP-MS instrument equipped with a $193 \mathrm{~nm}$ excimer laser at the State Key Laboratory of Geological Processes and Mineral Resources, China University of Geoscience, Wuhan, China. Zircon \#91500 was used as standard and NIST 610 was used to optimize the results. A spot diameter of $24 \mu \mathrm{m}$ was used. Prior to LA-ICP-MS 


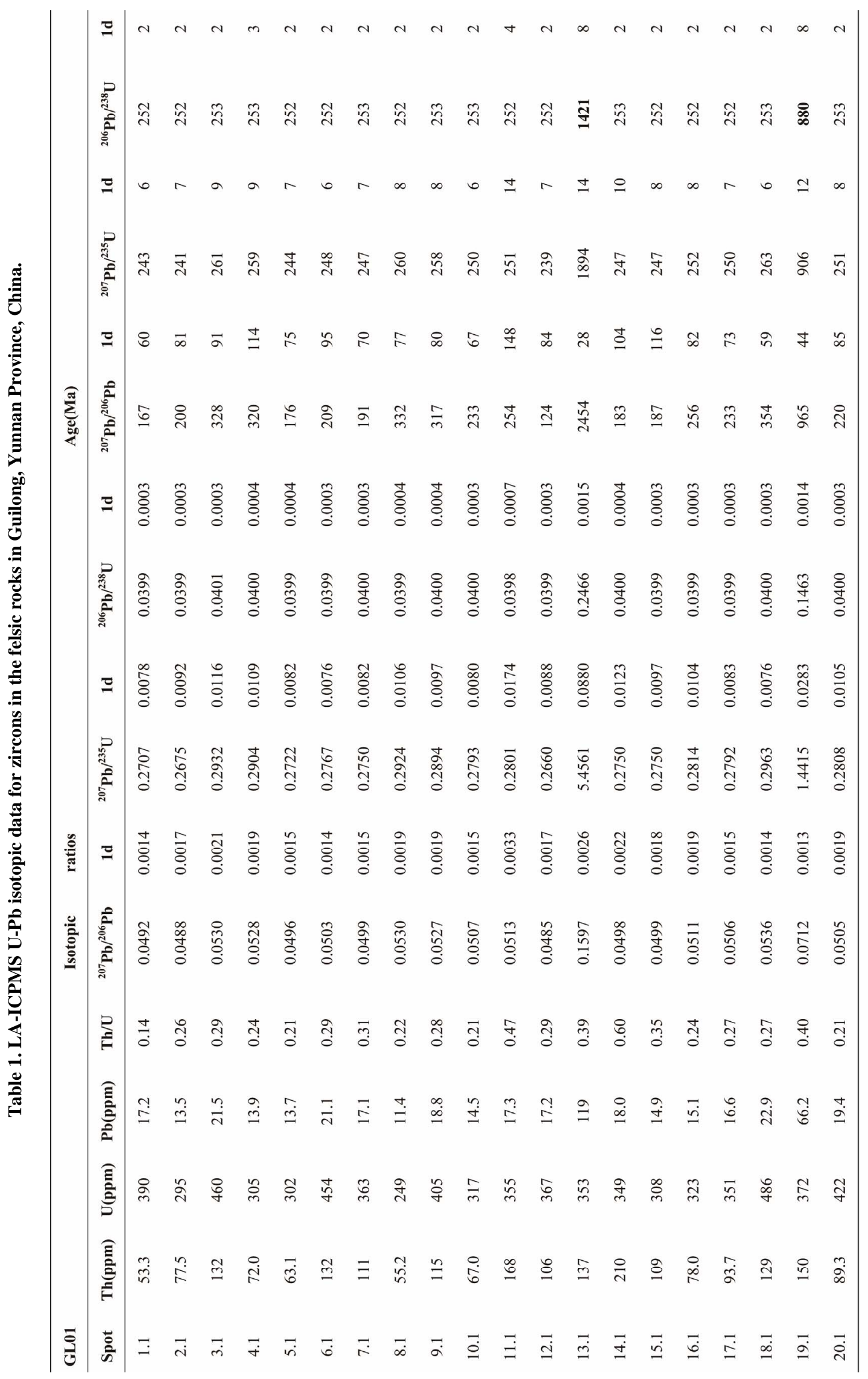




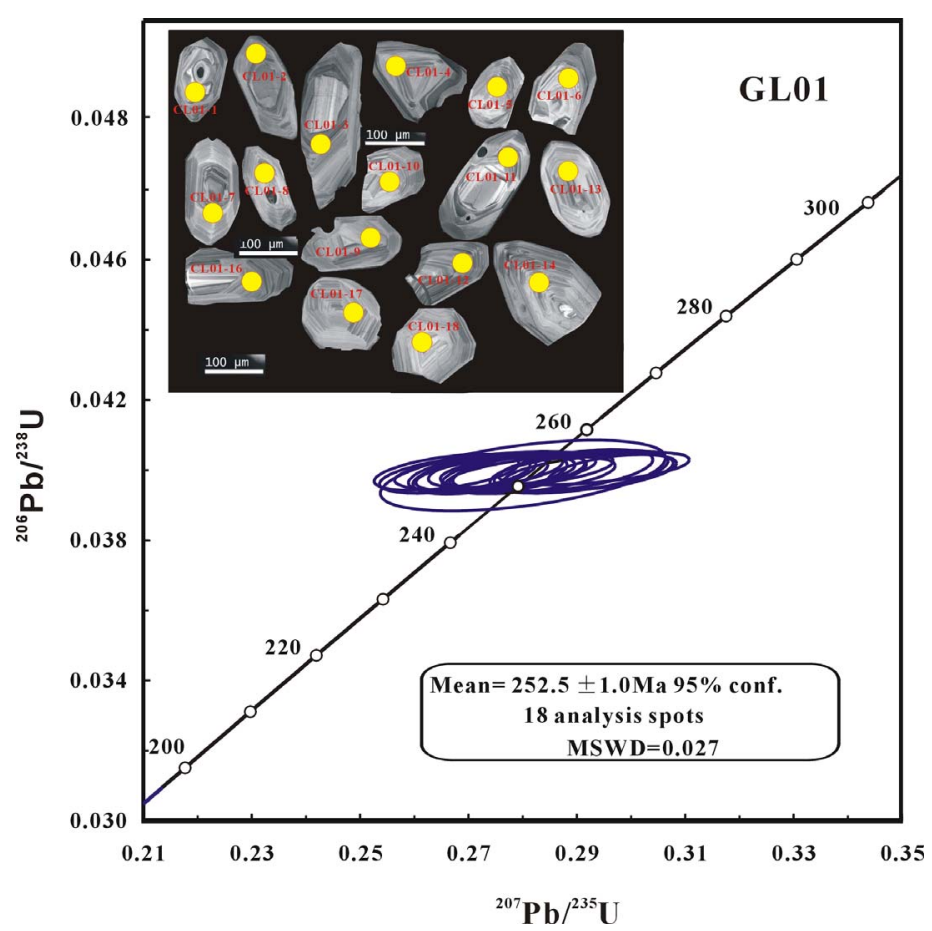

Figure 3. Selected zircon CL images and the LA-ICP-MS zircon U-Pb concordia diagram for the granodiorite (GL01) in Guilong, Southeastern Yunnan Province.

zircon $\mathrm{U}-\mathrm{Pb}$ dating, the surfaces of the grain mounts were washed in dilute $\mathrm{HNO}_{3}$ and pure alcohol to remove any potential lead contamination. The analytical methodology has been described in detail by Yuan et al. (2004) [15]. Correction for common $\mathrm{Pb}$ was performed following Andersen (2002) [16]. Data were processed using the GLITTER and ISOPLOT programs [17] (Table 1; Figure 3). Errors for individual analyses by LA-ICP-MS were quoted at the $95 \%(1 \sigma)$ confidence level.

\subsection{Major Elemental, Trace Elemental and Isotopic Analyses}

Twenty-seven samples were collected to carry out major and trace element determinations and $\mathrm{Sr}-\mathrm{Nd}$ isotopic analyses. Whole-rock samples were trimmed to remove altered surfaces, cleaned with deionized water and then crushed and powdered using an agate mill.

Major elements were analyzed using PANalytical Axios-advance (Axios PW4400) X-Ray Fluorescence spectrometer (XRF) at the State Key Laboratory of Ore Deposit Geochemistry, Institute of Geochemistry, Chinese Academy of Sciences. Fused glass disks were used. Based on the Chinese National standards GSR-1 and GSR-3 (Table 2), analytical precision was better than 5\%. Loss on Ignition (LOI) was obtained using $1 \mathrm{~g}$ of powder heated to $1100^{\circ} \mathrm{C}$ for $1 \mathrm{~h}$.

Trace elements were analyzed by plasma optical emission MS ICP-MS at the National Research Center of Geoanalysis, Chinese Academy of Geosciences follow- ing the procedures described by Qi et al. (2000) [18]. The discrepancy among triplicates was less than 5\% for all elements. Analysis results of the international standards OU-6 and GBPG-1 were consistent with the recommended values (Table 3).

For the analyses of $\mathrm{Rb}-\mathrm{Sr}$ and $\mathrm{Sm}-\mathrm{Nd}$ isotopes, sample powders were spiked with mixed isotope tracers, dissolved in Teflon capsules with $\mathrm{HF}+\mathrm{HNO}_{3}$ acids and separated by conventional cation-exchange techniques. Isotopic measurements were performed using a Finnigan Triton Ti thermal ionization mass spectrometer at the State Key Laboratory of Geological Processes and Mineral Resources, China University of Geosciences, Wuhan, China. Procedural blanks were $<200 \mathrm{pg}$ for Sm and $\mathrm{Nd}$ and $<500 \mathrm{pg}$ for $\mathrm{Rb}$ and $\mathrm{Sr}$. Mass fractionation corrections for $\mathrm{Sr}$ and $\mathrm{Nd}$ isotopic ratios were based on ${ }^{86} \mathrm{Sr} /{ }^{88} \mathrm{Sr}=0.1194$ and ${ }^{146} \mathrm{Nd} /{ }^{144} \mathrm{Nd}=0.7219$, respectively. Analyses of standards yielded the following results: NBS987 gave ${ }^{87} \mathrm{Sr} /{ }^{86} \mathrm{Sr}=0.710246 \pm 16(2 \sigma)$ and $\mathrm{La}$ Jolla gave ${ }^{143} \mathrm{Nd} /{ }^{144} \mathrm{Nd}=0.511863 \pm 8(2 \sigma)$. The analyticcal results for $\mathrm{Sr}-\mathrm{Nd}$ isotopes are presented in Table 4 .

\section{Results}

\subsection{Zircon U-Pb Age}

Euhedral zircon grains in samples GL01 are clean and prismatic, with magmatic oscillatory zoning. A total of 18 grains have a weighted mean ${ }^{206} \mathrm{~Pb} /{ }^{238} \mathrm{U}$ age of 252.5 $\pm 1.0 \mathrm{Ma}(1 \sigma)(95 \%$ confidence interval) for GL01 (Ta- 
ble 1; Figure 3). These determinations are the best estimates of the crystallization ages of the granodiorites. Some inherited zircons (1421 and $880 \mathrm{Ma}$; Table 1) are present in the rock.

\subsection{Major and Trace Elements}

Geochemical data on the granodiorites in the study area are listed in Tables $\mathbf{2}$ and $\mathbf{3}$.
The granodiorites have a relatively wide range of chemical compositions, with $\mathrm{SiO}_{2}=65.73 \mathrm{wt} \%$ to 69.94 $\mathrm{wt} \%, \mathrm{Al}_{2} \mathrm{O}_{3}=13.04 \mathrm{wt} \%$ to $14.11 \mathrm{wt} \%, \mathrm{MgO}=1.41 \mathrm{wt} \%$ to $1.90 \mathrm{wt} \%\left(\mathrm{Mg}^{\#}=40\right.$ to 46$), \mathrm{Fe}_{2} \mathrm{O}_{3}=4.67 \mathrm{wt} \%$ to 5.59 $\mathrm{wt} \%, \mathrm{CaO}=0.72 \mathrm{wt} \%$ to $2.72 \mathrm{wt} \%, \mathrm{~K}_{2} \mathrm{O}=3.71 \mathrm{wt} \%$ to $4.98 \mathrm{wt} \%$ and $\mathrm{Na}_{2} \mathrm{O}=2.45 \mathrm{wt} \%$ to $4.03 \mathrm{wt} \%$. They have consistent $\mathrm{TiO}_{2}=0.67 \mathrm{wt} \%$ to $0.81 \mathrm{wt} \%, \mathrm{MnO}=0.06$ wt $\%$ to 0.08 wt $\%$ and $\mathrm{P}_{2} \mathrm{O}_{5}=0.14 \mathrm{wt} \%$ to $0.16 \mathrm{wt} \%$.

Table 2. Major oxides (wt\%) for the felsic rocks in Guilong, Yunnan Province, China.

\begin{tabular}{|c|c|c|c|c|c|c|c|c|c|c|c|c|c|c|c|}
\hline Sample & Rock type & $\mathrm{SiO}_{2}$ & $\mathrm{TiO}_{2}$ & $\mathrm{Al}_{2} \mathrm{O}_{3}$ & $\mathrm{Fe}_{2} \mathrm{O}_{3}$ & $\mathrm{MnO}$ & $\mathrm{CaO}$ & $\mathrm{MgO}$ & $\mathrm{K}_{2} \mathrm{O}$ & $\mathrm{Na}_{2} \mathrm{O}$ & $\mathrm{P}_{2} \mathrm{O}_{5}$ & LOI & Total & $\mathrm{Mg}^{\#}$ & $\mathrm{~T}_{\mathrm{Zr}}\left({ }^{\circ} \mathrm{C}\right)$ \\
\hline GL-1 & granodiorite & 66.91 & 0.71 & 13.04 & 4.75 & 0.08 & 2.72 & 1.59 & 4.44 & 2.57 & 0.15 & 2.36 & 99.32 & 42 & 840 \\
\hline GL-2 & granodiorite & 67.47 & 0.77 & 14.06 & 5.21 & 0.07 & 0.74 & 1.72 & 4.12 & 4.03 & 0.16 & 1.76 & 100.11 & 42 & 844 \\
\hline GL-3 & granodiorite & 68.94 & 0.71 & 13.34 & 4.67 & 0.07 & 1.00 & 1.51 & 4.48 & 3.50 & 0.15 & 1.81 & 100.17 & 42 & 846 \\
\hline GL-4 & granodiorite & 66.82 & 0.67 & 13.57 & 4.70 & 0.07 & 1.81 & 1.56 & 4.18 & 2.84 & 0.14 & 2.75 & 99.11 & 42 & 857 \\
\hline GL-5 & granodiorite & 66.85 & 0.74 & 13.63 & 5.07 & 0.08 & 1.43 & 1.71 & 4.66 & 2.54 & 0.15 & 2.37 & 99.22 & 43 & 842 \\
\hline GL-6 & granodiorite & 67.29 & 0.74 & 13.72 & 5.10 & 0.07 & 0.93 & 1.66 & 4.67 & 2.53 & 0.16 & 2.38 & 99.25 & 42 & 873 \\
\hline GL-7 & granodiorite & 67.82 & 0.81 & 14.07 & 4.96 & 0.07 & 0.99 & 1.68 & 4.81 & 2.65 & 0.16 & 1.86 & 99.87 & 43 & 886 \\
\hline GL-8 & granodiorite & 67.53 & 0.75 & 13.56 & 4.96 & 0.06 & 1.04 & 1.41 & 4.79 & 2.57 & 0.16 & 2.36 & 99.18 & 38 & 853 \\
\hline GL-9 & granodiorite & 68.00 & 0.76 & 13.78 & 5.00 & 0.08 & 0.91 & 1.69 & 4.83 & 2.52 & 0.16 & 2.14 & 99.87 & 43 & 867 \\
\hline GL-10 & granodiorite & 68.96 & 0.74 & 13.79 & 5.08 & 0.07 & 1.07 & 1.67 & 4.76 & 2.56 & 0.15 & 1.35 & 100.20 & 42 & 838 \\
\hline GL-11 & granodiorite & 65.73 & 0.77 & 14.03 & 5.59 & 0.08 & 0.73 & 1.90 & 4.81 & 2.58 & 0.16 & 2.76 & 99.13 & 43 & 875 \\
\hline GL-12 & granodiorite & 69.11 & 0.75 & 13.95 & 5.05 & 0.06 & 0.72 & 1.52 & 4.41 & 2.99 & 0.16 & 1.42 & 100.13 & 40 & 839 \\
\hline GL-13 & granodiorite & 68.72 & 0.69 & 13.46 & 4.65 & 0.07 & 1.45 & 1.56 & 4.72 & 2.59 & 0.14 & 1.85 & 99.91 & 42 & 825 \\
\hline GL-14 & granodiorite & 68.13 & 0.75 & 13.79 & 4.88 & 0.07 & 0.93 & 1.67 & 4.87 & 2.52 & 0.16 & 2.33 & 100.10 & 43 & 846 \\
\hline GL-15 & granodiorite & 67.94 & 0.75 & 13.63 & 4.86 & 0.08 & 1.75 & 1.58 & 4.37 & 2.83 & 0.15 & 1.98 & 99.92 & 42 & 825 \\
\hline GL-16 & granodiorite & 68.46 & 0.72 & 13.35 & 5.35 & 0.08 & 0.97 & 1.65 & 3.71 & 3.48 & 0.15 & 1.99 & 99.91 & 40 & 840 \\
\hline GL-17 & granodiorite & 67.54 & 0.74 & 13.64 & 5.07 & 0.06 & 1.05 & 1.62 & 4.79 & 2.60 & 0.16 & 2.31 & 99.58 & 41 & 845 \\
\hline GL-18 & granodiorite & 66.21 & 0.72 & 13.63 & 5.17 & 0.07 & 1.43 & 1.54 & 4.77 & 2.86 & 0.15 & 2.63 & 99.18 & 42 & 839 \\
\hline GL-19 & granodiorite & 68.04 & 0.76 & 13.94 & 5.2 & 0.07 & 1.19 & 1.62 & 4.90 & 2.45 & 0.16 & 1.75 & 100.07 & 41 & 851 \\
\hline GL-20 & granodiorite & 69.13 & 0.74 & 13.61 & 5.11 & 0.08 & 1.19 & 1.66 & 4.44 & 2.67 & 0.15 & 1.45 & 100.22 & 42 & 835 \\
\hline GL-21 & granodiorite & 66.88 & 0.73 & 13.86 & 4.78 & 0.06 & 0.93 & 1.55 & 4.97 & 2.99 & 0.16 & 2.37 & 99.28 & 42 & 845 \\
\hline GL-22 & granodiorite & 67.75 & 0.75 & 13.68 & 5.14 & 0.08 & 1.38 & 1.71 & 4.36 & 2.77 & 0.15 & 2.24 & 100.01 & 42 & 841 \\
\hline GL-23 & granodiorite & 69.94 & 0.77 & 13.79 & 5.15 & 0.07 & 0.85 & 1.60 & 4.84 & 2.70 & 0.16 & 0.56 & 100.43 & 41 & 852 \\
\hline GL-24 & granodiorite & 67.65 & 0.72 & 13.84 & 4.84 & 0.06 & 0.90 & 1.58 & 4.96 & 2.58 & 0.15 & 2.12 & 99.39 & 43 & 839 \\
\hline GL-25 & granodiorite & 69.11 & 0.72 & 13.94 & 4.71 & 0.07 & 1.16 & 1.52 & 4.88 & 2.69 & 0.15 & 1.21 & 100.16 & 46 & 847 \\
\hline GL-26 & granodiorite & 69.13 & 0.75 & 14.11 & 5.00 & 0.07 & 1.30 & 1.63 & 4.98 & 2.62 & 0.15 & 0.38 & 100.13 & 45 & 848 \\
\hline GL-27 & granodiorite & 68.92 & 0.75 & 13.92 & 5.54 & 0.10 & 1.16 & 1.56 & 4.71 & 2.74 & 0.16 & 0.57 & 100.13 & 41 & 857 \\
\hline GSR-3 & $\mathrm{RV}^{*}$ & 44.64 & 2.37 & 13.83 & 13.4 & 0.17 & 8.81 & 7.77 & 2.32 & 3.38 & 0.95 & 2.24 & 99.88 & - & - \\
\hline GSR-3 & $\mathrm{MV}^{*}$ & 44.75 & 2.36 & 14.14 & 13.35 & 0.16 & 8.82 & 7.74 & 2.3 & 3.18 & 0.97 & 2.12 & 99.89 & - & - \\
\hline GSR-1 & $\mathrm{RV}^{*}$ & 72.83 & 0.29 & 13.4 & 2.14 & 0.06 & 1.55 & 0.42 & 5.01 & 3.13 & 0.09 & 0.7 & 99.62 & - & - \\
\hline GSR-1 & $M V^{*}$ & 72.65 & 0.29 & 13.52 & 2.18 & 0.06 & 1.56 & 0.46 & 5.03 & 3.15 & 0.11 & 0.69 & 99.70 & - & - \\
\hline
\end{tabular}

Note: $\mathrm{LOI}$, loss on ignition. $\mathrm{Mg}^{\#}=100 \times \mathrm{Mg} /\left(\mathrm{Mg}+\sum \mathrm{Fe}\right)$ atomic ratio. “-”, not caculated. $\mathrm{T}_{\mathrm{Zr}}\left({ }^{\circ} \mathrm{C}\right)$ is calculated from zircon saturation thermometry [33]. $\mathrm{RV}$, recommended values; MV*, measured values. The values for GSR-1 and GSR-3 are from Wang et al. (2003) [38]. 


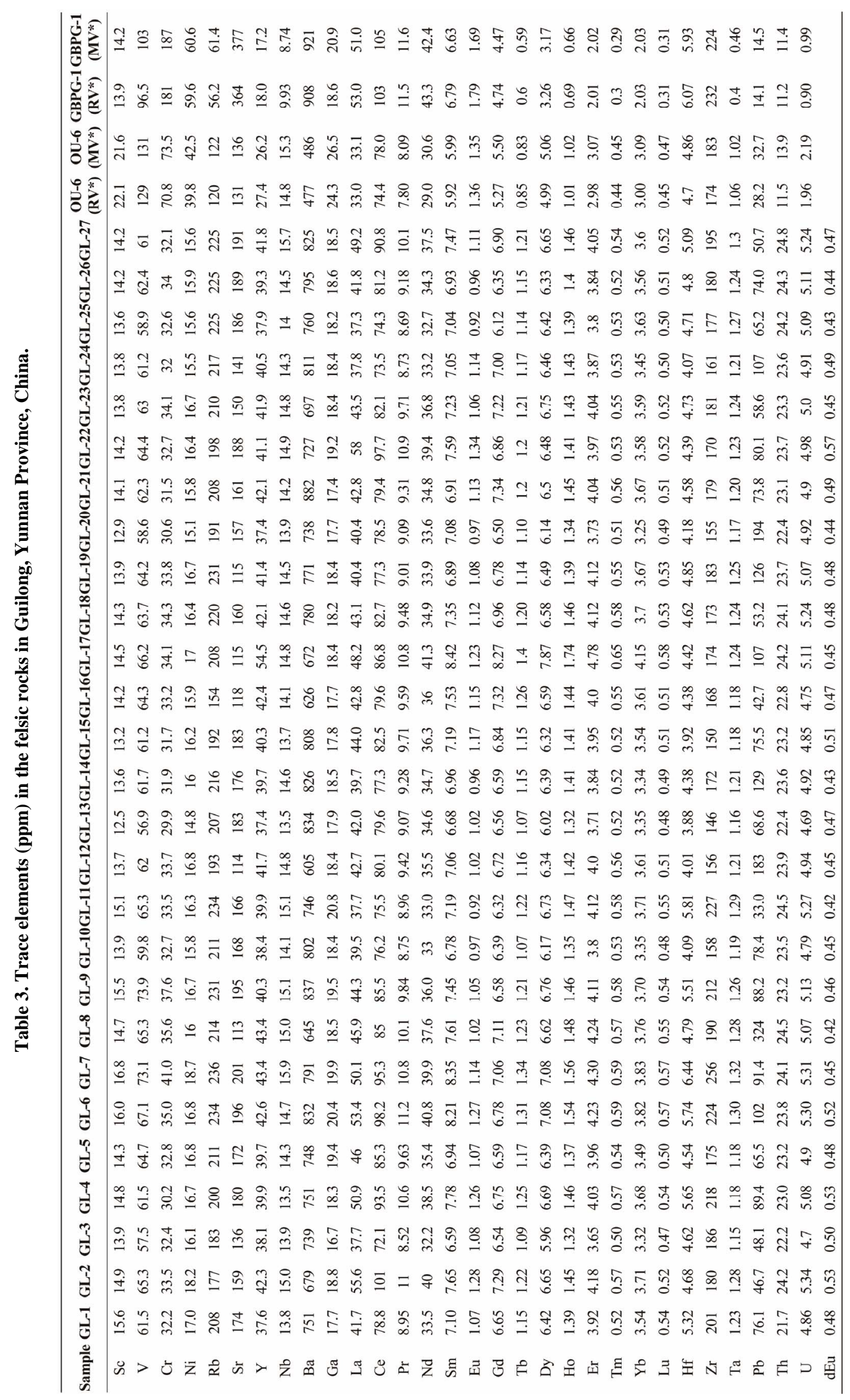


The granodiorites are relatively high in total alkalis, with $\mathrm{K}_{2} \mathrm{O}+\mathrm{Na}_{2} \mathrm{O}$ ranging from $7.02 \mathrm{wt} \%$ to $8.15 \mathrm{wt} \%$. All granodiorites in the calc-alkaline field are plotted on the Total Alkali-Silica (TAS) diagram (Figure 4(a)). All samples also straddle the shoshonitic series in the $\mathrm{Na}_{2} \mathrm{O}$ vs $\mathrm{K}_{2} \mathrm{O}$ plot (Figure 4(b)). In the plot of the molar ratios of $\mathrm{Al}_{2} \mathrm{O}_{3} /\left(\mathrm{Na}_{2} \mathrm{O}+\mathrm{K}_{2} \mathrm{O}\right)$ and $\mathrm{Al}_{2} \mathrm{O}_{3} /\left(\mathrm{CaO}+\mathrm{Na}_{2} \mathrm{O}+\mathrm{K}_{2} \mathrm{O}\right)$, the rocks are mostly peraluminous, except for one sample falling the metaluminous field (Figure 4(c)). The granodiorites display almost unchanged $\mathrm{TiO}_{2}, \mathrm{Al}_{2} \mathrm{O}_{3}, \mathrm{Fe}_{2} \mathrm{O}_{3}$, $\mathrm{MgO}, \mathrm{CaO}, \mathrm{Na}_{2} \mathrm{O}+\mathrm{K}_{2} \mathrm{O}, \mathrm{MnO}, \mathrm{P}_{2} \mathrm{O}_{5}, \mathrm{Rb}, \mathrm{Cr}$ and $\mathrm{Ni}$, relatively decreasing $\mathrm{Zr}$ and increasing $\mathrm{SiO}_{2}$. They have no correlations among $\mathrm{Sr}, \mathrm{Ba}$ and $\mathrm{SiO}_{2}$ (Figures 5 and 6).

All granodiorites are characterized by Light Rare Earth Element (LREE) enrichment and Heavy Rare Earth Element (HREE) depletion, with a wide range of $(\mathrm{La} / \mathrm{Yb})_{\mathrm{N}}$ values (7.29 to 11.62 ) and slight negative $\mathrm{Eu}$ anomalies $\left(\mathrm{Eu} / \mathrm{Eu}^{*}=0.42\right.$ to 0.57$)$ (Table 3 and Figure 7(a)). In the primitive mantle-normalized trace element diagrams, the granodiorites show enrichment in Large Ion Lithophile Elements (LILE) (i.e., $\mathrm{Rb}, \mathrm{Pb}$ and $\mathrm{U}$ ) and depletion in $\mathrm{Ba}$, $\mathrm{Sr}$ and High Field Strength Elements (HFSE) (i.e., Nb, Ta, $\mathrm{P}$ and Ti) (Figure 7(b)).

\subsection{Sr-Nd and Pb Isotopes}

$\mathrm{Sr}-\mathrm{Nd}$ isotopic data have been obtained from representative granodiorite samples (Table 4). The felsic rocks show uniform $\left({ }^{87} \mathrm{Sr} /{ }^{86} \mathrm{Sr}\right)_{i}$ values, ranging from 0.7231 to 0.7237 and relatively little variation in initial. $\varepsilon_{\mathrm{Nd}}(t)$ values from -29.1 to -30.4 , suggesting an enriched source region. The $\mathrm{Sr}-\mathrm{Nd}$ isotopic compositions (Figure 8) are also comparable with the upper crust.

\section{Discussion}

\subsection{Mantle Contribution}

Currently, the interaction between crust and mantle is very important for the genetic investigation of granitoid rocks. Previous studies suggest that mantle contribution (e.g., material and energy) during granitoid rock formation cannot be ignored [19-21].

The REE of the granodiorites $\left[\Sigma \mathrm{REE}=181^{\circ} \mathrm{ppm}\right.$ to $242^{\circ} \mathrm{ppm},(\mathrm{La} / \mathrm{Yb})_{\mathrm{N}}=7.29$ to $11.62, \delta \mathrm{Eu}=0.42$ to 0.57$]$ has some visible differences with that of granitoid rocks formed by re-melting of the continental crust with high maturity, such as Suidong intrusion in Southern China $\left[\Sigma \mathrm{REE}=169^{\circ} \mathrm{ppm}\right.$ to $268^{\circ} \mathrm{ppm},(\mathrm{La} / \mathrm{Yb})_{\mathrm{N}}=6.44$ to $10.74, \delta \mathrm{Eu}=0.14$ to 0.31 [22]. However, the REE can be comparable with that of syntactic-type granitic rocks involving obvious mantle material in their petrogenesis in southern China, e.g., Wuping intrusion [ $\mathrm{\Sigma REE}=103^{\circ}$ ppm to $395^{\circ} \mathrm{ppm},(\mathrm{La} / \mathrm{Yb})_{\mathrm{N}}=5.3$ to $38.7, \delta \mathrm{Eu}=0.34$ to $0.56]$ [23] and Longwo intrusion $\left[\Sigma \mathrm{REE}=103^{\circ} \mathrm{ppm}\right.$ to
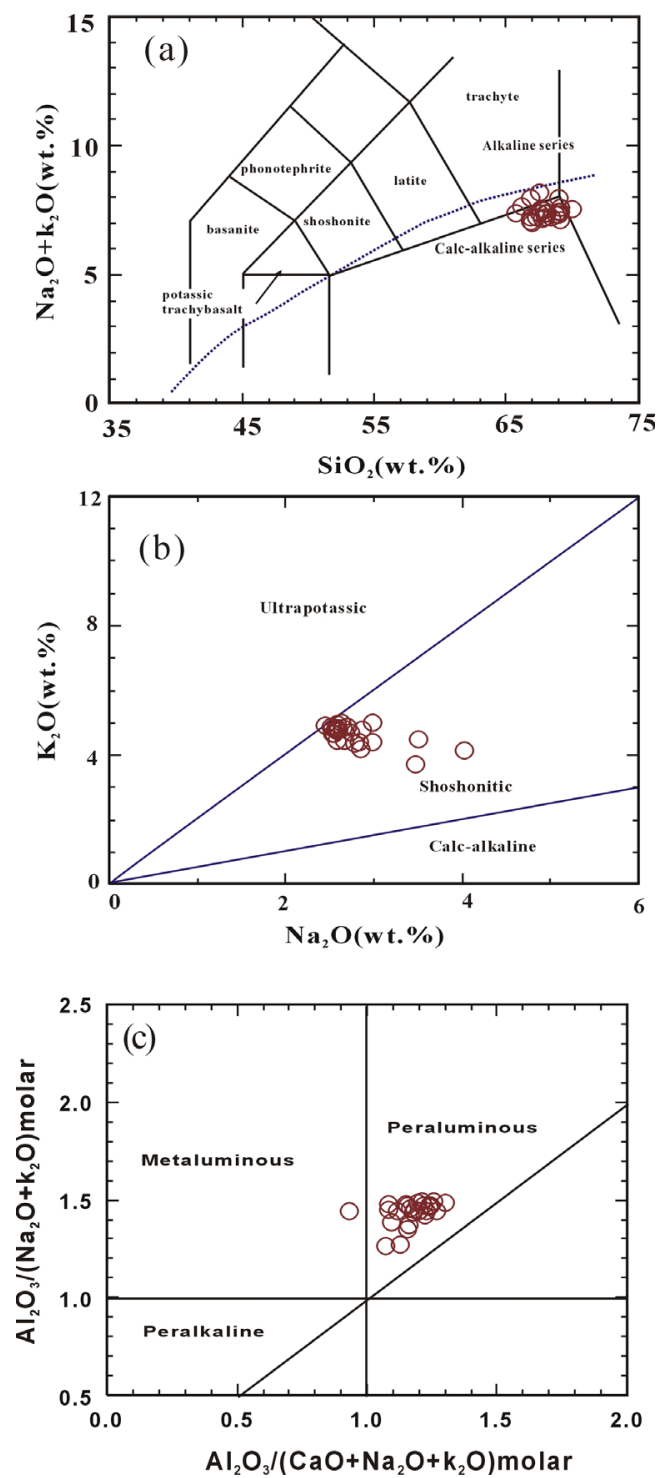

Figure 4. Classification of the granodiorites in Southeastern Yunnan province based on three diagrams. (a) TAS diagram. All major elemental data have been recalculated to $100 \%$ on a LOI-free basis [34-35]. (b) $\mathrm{K}_{2} \mathrm{O}$ vs $\mathrm{Na}_{2} \mathrm{O}$ diagram. The granodiorites are shown to be shoshonitic [36]. (c) $\mathrm{Al}_{2} \mathrm{O}_{3} /\left(\mathrm{Na}_{2} \mathrm{O}+\mathrm{K}_{2} \mathrm{O}\right)$ molar vs $\mathrm{Al}_{2} \mathrm{O}_{3} /\left(\mathrm{CaO}+\mathrm{Na}_{2} \mathrm{O}+\mathrm{K}_{2} \mathrm{O}\right)$ molar plot. Most samples fall in the peraluminous field. However, one sample straddles the metaluminous field.

$196^{\circ} \mathrm{ppm},(\mathrm{La} / \mathrm{Yb})_{\mathrm{N}}=4.5$ to $35.7, \delta \mathrm{Eu}=0.41$ to 0.62$]$ [24].

The granodiorites in the present study have relatively higher compatible element contents $\left(\mathrm{V}=58.6^{\circ} \mathrm{ppm}\right.$ to $73.1^{\circ} \mathrm{ppm}, \mathrm{Cr}=29.9^{\circ} \mathrm{ppm}$ to $41.0^{\circ} \mathrm{ppm}, \mathrm{Ni}=14.8^{\circ} \mathrm{ppm}$ to $18.7^{\circ} \mathrm{ppm}$ ) than some granitic rocks formed by the interaction of crust and mantle in the Yangtze River and southern China (Wuping biotite monzogranite [23]; granodiorites in Longwo [24,25]). In addition, the high $\mathrm{Mg}^{\#}$ (43 46; Table 2) of the rocks agrees with interaction of crust and mantle. Simutaneously, the $\mathrm{Sr}-\mathrm{Nd}$ isotopic signatures 

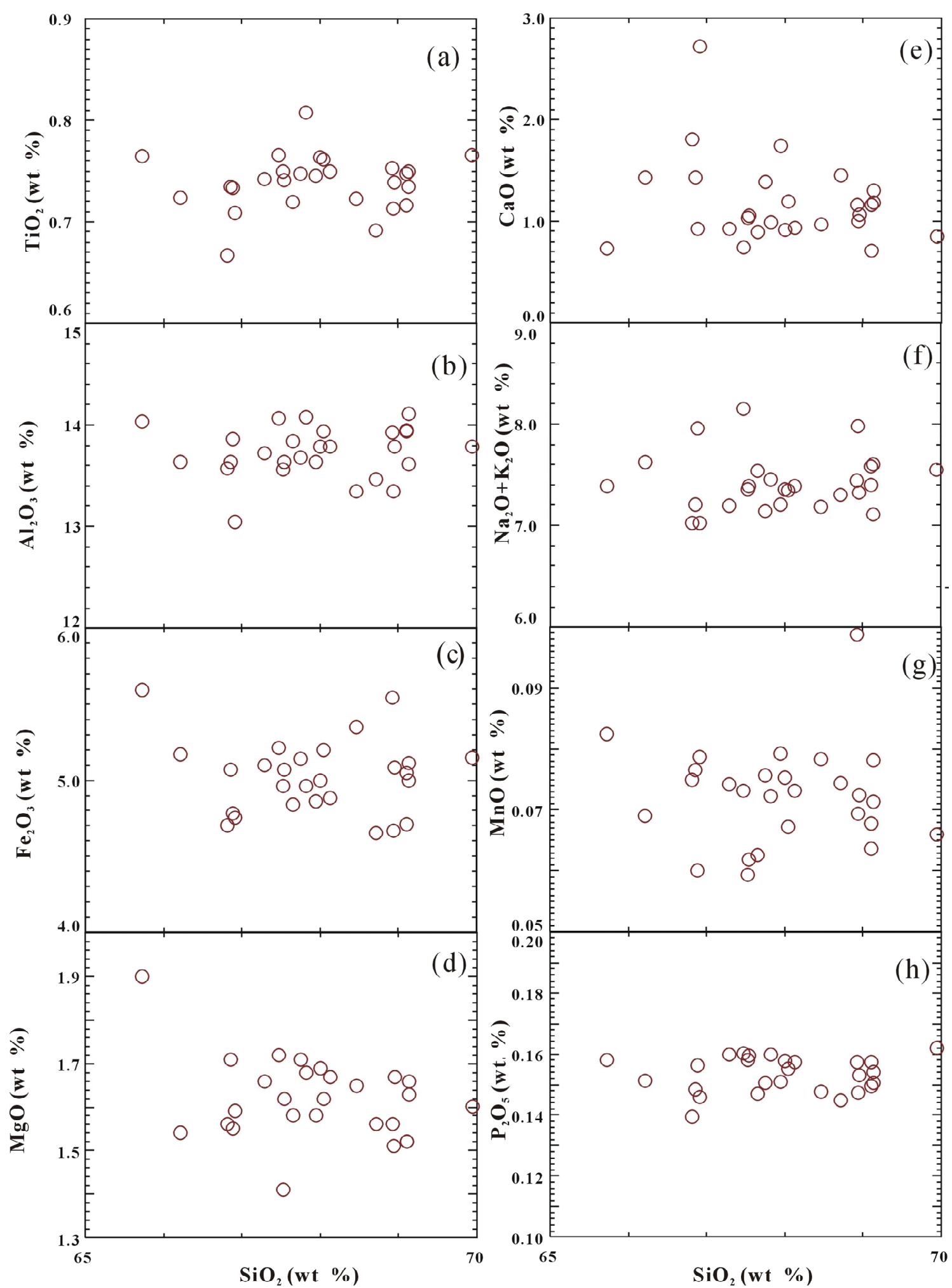

Figure 5. Selected variation diagrams of major elemental oxides vs $\mathrm{SiO}_{2}$ plots for the felsic rocks in Southeastern Yunnan Province.

of the granodiorites are comparable with those in the associated mafic dykes (lamprophyres) in the study area (Figure 1).
In summary, this evidence indicates that evident mantle materials contributed to the diagenesis of Guilong granodiorites in Yunnan Province. 

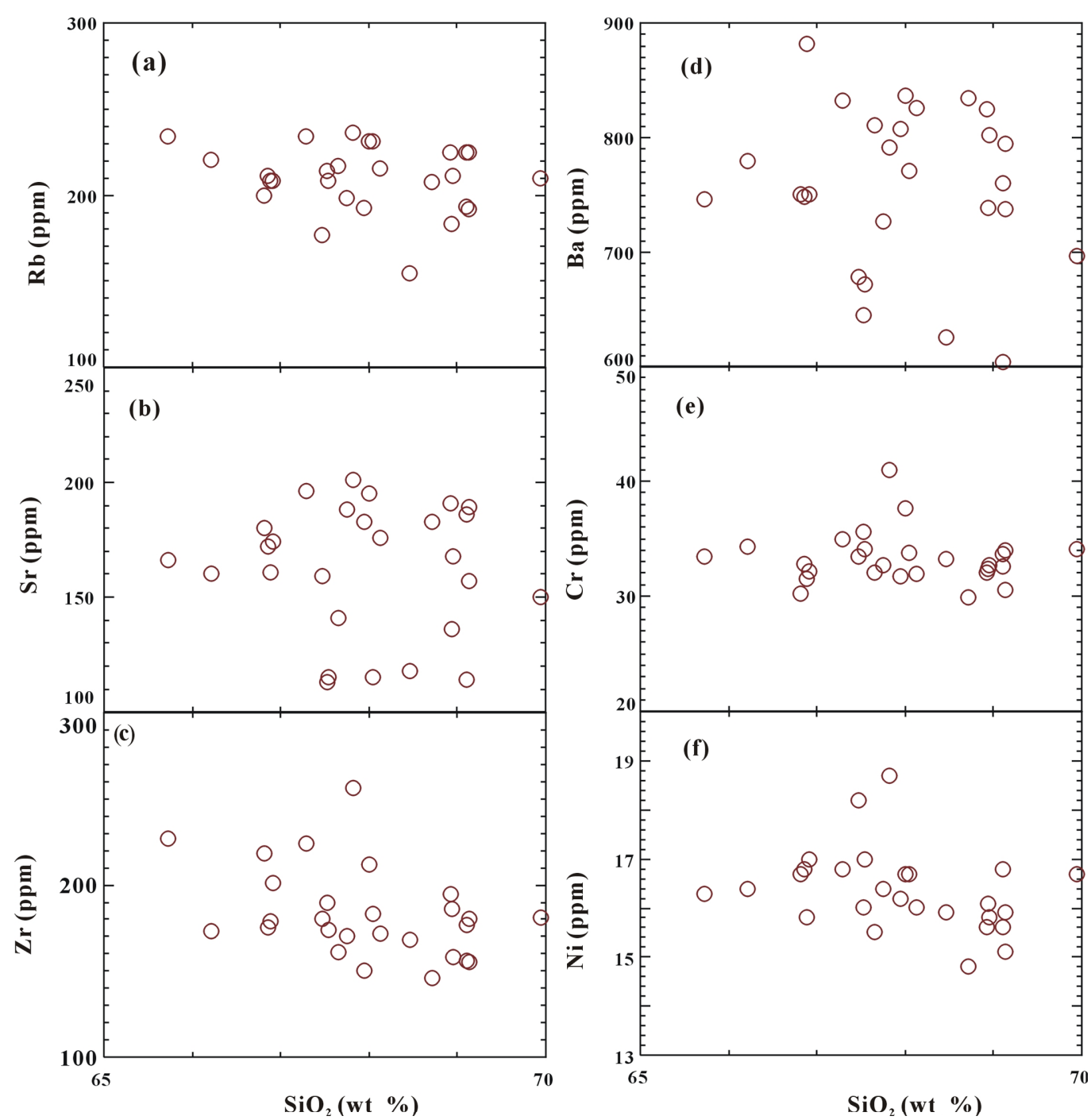

Figure 6. Selected variation diagrams of trace elements vs $\mathrm{SiO}_{2}$ plots for the felsic rocks in Southeastern Yunnan Province.
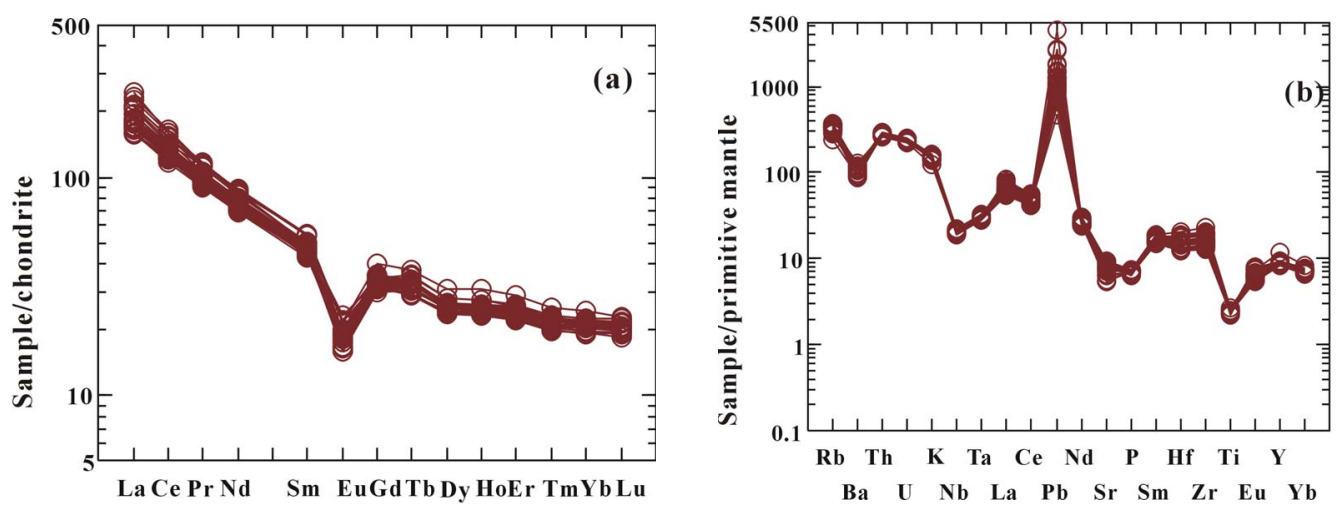

Figure 7. (a) Chondrite-normalized REE diagrams; (b) Primitive mantle-normalized trace element spidergrams for the granodiorites in Southeastern Yunnan Province. The normalization values are from Sun and McDonough (1989) [37].

\subsection{Crustal Contamination}

Assimilation, crystal fractionation (AFC), or magma mixing is usually postulated to explain the occurrence of comagmatic felsic rocks [26-29]. AFC and magma mixing result in a positive correlation between $\mathrm{SiO}_{2}$ and $\varepsilon_{\mathrm{Nd}}$ $(t)$ values and a negative correlation between $\mathrm{SiO}_{2}$ and 


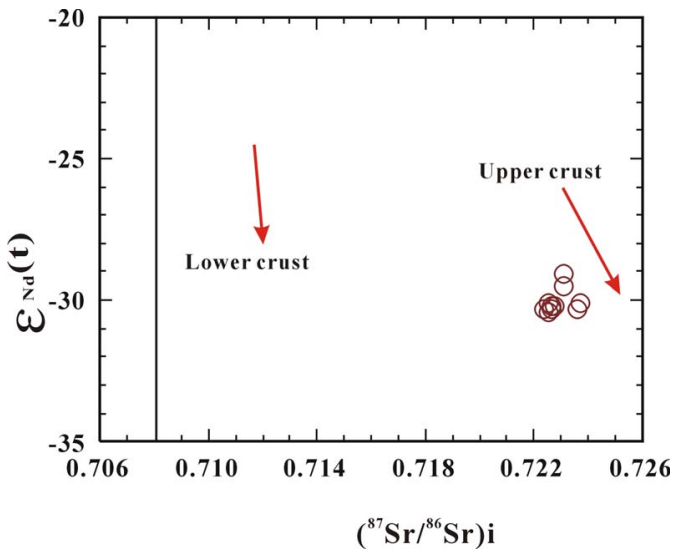

Figure 8. Initial ${ }^{87} \mathrm{Sr} /{ }^{86} \mathrm{Sr}$ vs $\varepsilon_{\mathrm{Nd}}(t)$ diagram for the felsic rocks in Southeastern Yunnan Province.

$\left({ }^{87} \mathrm{Sr}{ }^{86} \mathrm{Sr}\right){ }_{i}$ ratios (Figure 9). However, these features are not observed in the studied granodiorites, indicating that magma evolution is insignificantly affected by crustal contamination or magma mixing. Therefore, the geochemical and $\mathrm{Sr}-\mathrm{Nd}$ isotopic signatures of the granodiorites are mainly inherited from an enriched source.

\subsection{Origin of the Rocks and Fractional Crystallization}

The granodiorites have relatively low $\mathrm{Al}_{2} \mathrm{O}_{3} / \mathrm{TiO}_{2}$ (17.4 to 20.3), suggesting that the temperature of partial melting is high $\left(>875^{\circ} \mathrm{C}[30]\right)$. Moreover, felsic rocks have low $\operatorname{Sr}\left(113^{\circ} \mathrm{ppm}\right.$ to $\left.201^{\circ} \mathrm{ppm}\right)$ and high $\mathrm{Yb}\left(3.25^{\circ} \mathrm{ppm}\right.$ to $4.15^{\circ} \mathrm{ppm}$ ), with the lower $\mathrm{Sr}$ and higher $\mathrm{Yb}$ feature. In addition, the granodiorites are provided with low $(\mathrm{La} / \mathrm{Yb})_{\mathrm{N}}(7.29$ to 11.62$)$ and negative slight Eu negative $(\delta \mathrm{Eu}=0.42$ to 0.57$)$ (Table 3). Hence, the rocks resulted from relatively low pressure $\left(<1.2^{\circ} \mathrm{Gpa}\right)$ and a shallow source [31].

For the studied felsic samples, the negative $\mathrm{Nb}, \mathrm{Ta}$ and $\mathrm{Ti}$ anomalies in all rocks (Figure $\mathbf{7 ( b )}$ ) agree with the fractionation of such Fe-Ti oxides as rutile and ilmenite. The relatively negative $\mathrm{Ba}, \mathrm{Sr}$ and $\mathrm{Eu}$ anomalies of the rocks (Figures 7(a) and (b)) imply the fractionation of potassium feldspar and plagioclase.

Besides above, the granodiorites have characterized Sr-Nd isotopic compositions $\left(\left({ }^{87} \mathrm{Sr} r{ }^{86} \mathrm{Sr}\right)_{i}=0.7231-\right.$ $\left.0.7237, \varepsilon_{\mathrm{Nd}}(t)=-29.1--30.4\right)$. The geochemistry feature all indicate that the granodiorites were derived from partial melting of crust-derived sedimentary rocks. Moreover, interaction of crust and mantle occurred during origin of the granodiorites.

The granodiorites show relatively decreasing $\mathrm{Zr}$ with increasing $\mathrm{SiO}_{2}$ (Figure 6(c)). This result indicates that zircon was saturated in the magma, which was also controlled by fractional crystallization [32]. Zircon saturation thermometry [33] provides a simple and robust

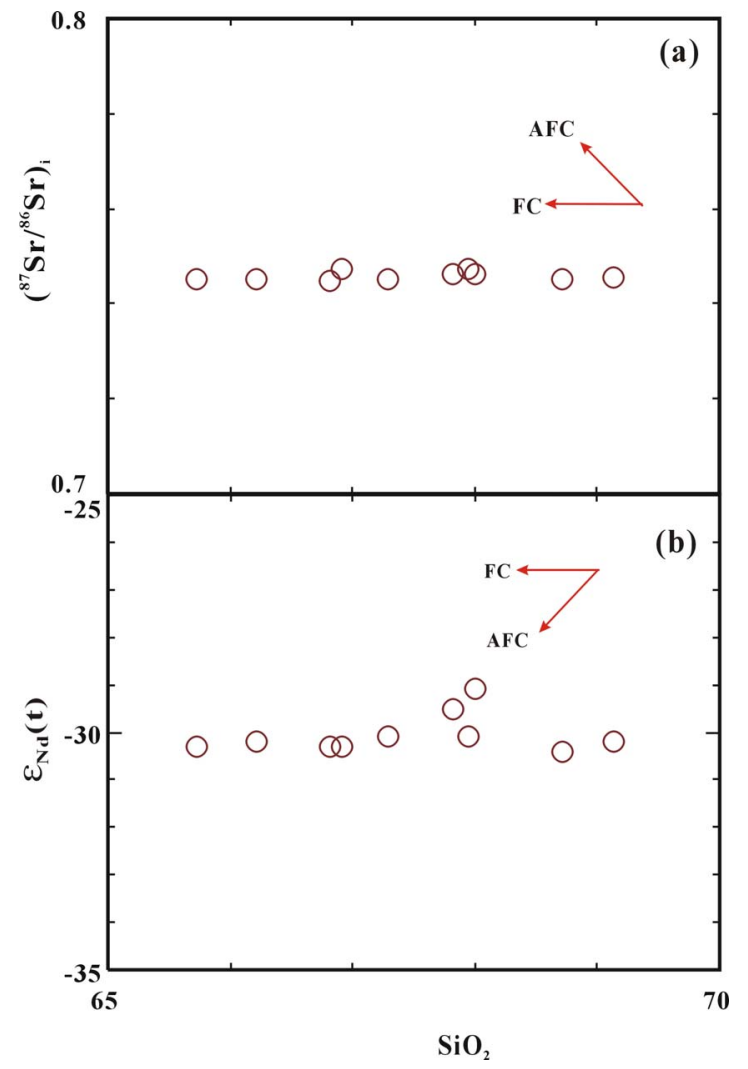

Figure 9. Plots of (a) initial ${ }^{87} \mathrm{Sr} /{ }^{86} \mathrm{Sr}$ ratio and (b) $\varepsilon_{\mathrm{Nd}}(t)$ value vs $\mathrm{SiO}_{2}$ for the felsic rocks in Southeastern Yunnan province, indicating crystal fractionation. FC, fractional crystallization; AFC, assimilation and fractional crystallization.

means of estimating magma temperatures from bulk-rock compositions. The calculated zircon saturation temperatures $\left(\mathrm{T}_{\mathrm{Zr}}\right)$ of felsic rocks are $825^{\circ} \mathrm{C}$ to $886^{\circ} \mathrm{C}$ (Table 2), representing the crystallization temperature of the magma.

\section{Conclusions}

Based on geochronological, geochemical and $\mathrm{Sr}-\mathrm{Nd}$ isotopic studies, the following conclusions are drawn:

1) Granodiorites were formed at $252.5 \pm 1.0$ based on LA-ICP-MS U-Pb zircon dating. The rocks resulted from post-collision magmatism.

2) Felsic rocks came from a crustal source. The fractionation of K-feldspar, plagioclase, ilmenite, or rutile, among others, resulted in granodiorites with negligible crustal contamination. The zircon saturation temperatures $\left(\mathrm{T}_{\mathrm{Zr}}\right)$ of the granodiorites range from $825^{\circ} \mathrm{C}$ to $875^{\circ} \mathrm{C}$, approximately representing the crystallization temperature of the magma.

\section{Acknowledgements}

The present research was supported by the Knowledge Innovation Project (KZCX2-YW-111-03) and the Na- 
tional Nature Science Foundation of China (40773020, 40972071, 90714010 and 40634020). The authors gratefully acknowledge Lian Zhou for helping analyze the $\mathrm{Sr}-\mathrm{Nd}$ isotopes and Yongsheng Liu and Zhaochu $\mathrm{Hu}$ for their help with the LA-ICP-MS zircon U-Pb dating.

\section{REFERENCES}

[1] Southwest Geological Exploration Corporation, "Geology of Tin Deposits in Gejiu," Metallurgical Industry Publishing House, Beijing, 1984.

[2] J. Chen, C. Hall and C. J. Stanley, "Tin-Bearing Skarns of South China: Geological Setting and Mineralogy," Ore Geology Reviews, Vol. 7, No. 3, 1992, pp. 225-248. doi:10.1016/0169-1368(92)90006-7

[3] Y. Q. Zhuang, R. Z. Wang and J. M. Yin, "Geology of the Gejiu Tin-Copper Olymetallic Deposit," Geological Publishing House, Beijing, 1996.

[4] Z. W. Jiang, N. H. S. Oliver, T. D. Barr W. L. Power and A. Ord, "Numerical Modeling of Fault-Controlled Fluid Flow in the Genesis of the Deposits of the Malage Ore District, Gejiu Mining District, China," Economic Geology, Vol. 92, No. 2. 1997, pp. 228-247. doi:10.2113/gsecongeo.92.2.228

[5] G. P. Mo, "Genetic Type of Granites in Gejiu Super Large Tin Polymetallic Deposit," Mineral Resources and Geology, Vol. 20, No. 45, 2006, pp. 413-417.

[6] Y. B. Cheng and J. W. Mao, "Age and Geochemistry of Granites in Gejiu Area, Yunnan Province, SW China: Constraints on Their Petrogenesis and Tectonic Setting," Lithos, Vol. 120, No. 3-4, 2010, pp. 258-276. doi:10.1016/j.lithos.2010.08.013

[7] The Second Geological Team of Yunnan Geological and Mineral Urea, "The Report of Prospecting at the Region of Bainiuchang in Mengzi County, Yunnan Province," Yunnan Ecological and Mineral Bureau, Mengzi County, 1990.

[8] Z. Y. Gao, "On the Genesis of the Bainiuchang SilverPolymetallic Deposit in Mengzi," Yunnan Geology, Vol. 15, No. 4, 1996, pp. 91-102.

[9] X. M. Chen, Z. Lin and F. H. Xie, "Geological and Geochemical Characteristics of the Bainiuehang Super Large Silver Polymetallic Deposit of Supreme Posed Mineralization, Yunnan Province," Scientia Geologica Sinica, Vol. 33, No. 1, 1998, pp. 115-123.

[10] X. B. Li, J. S. Liu, H. P. Zhang and G. Ma, "The Analysis to Ore-Controlling Factors of the Bainiuehang Ag Polymetallic Deposit of Mengzi County in Yunnan Province," Contribution to Geology and Mineral Resources Research, Vol. 20, No. 2, 2005, pp.111-114.

[11] H. J. Xie, C. H. Zhu, Q. Zhang, Q. Wang and L. W. Fan, "Sulfur Isotopic Composition of the Bainiuchang Super Large Ag Polymetallic Deposit, Yunnan Province, China: Implications for the Source of Sulfur in Ore Forming F1uids," Chinese Journal of Geochemistry, Vol. 28, No. 3, 2009, pp. 284-292. doi:10.1007/s11631-009-0284-6

[12] L. Ye, N. J. Cook, C. L. Ciobanu, Y. P. Liu, Q. Zhang, T.
G. Liu, W. Gao, Y. L. Yang and L. Danyushevskiy, "Trace and Minor Elements in Sphalerite from Base Metal Deposits in South China: A La-Icpms Study," Ore Geology Reviews, Vol. 39, No. 4, 2011, pp. 188-217. doi:10.1016/j.oregeorev.2011.03.001

[13] C. H. Zhu, Q. Zhang, S. X. Shao and D. P. Wang, "Origin of Bainiuchang Liver-Polymetallic Deposit in Yunnan, China," Global Geology, Vol. 25, No. 4, 2006, pp. 353359.

[14] C. H. Zhu, Q. Zhang, S. X. Shao, X. Q. Zhu and D. Q. Wang, "Lead Isotopic Composition and Lead Source in the Bainiuchang Ag-Polymetallic Deposit, Yunnan Province, China," Acta Geologica Sinica, Vol. 82, No. 5, 2008, pp. 845-857.

[15] H. L. Yuan, S. Gao, X. M. Liu, H. M. Li, D. Gunther and F. Y. Wu, "Accurate U-Pb Age and Trace Element Determinations of Zircon by Laser Ablation-Inductively Coupled Plasma Mass Spectrometry," Geostandards Newsletter, Vol. 28, No. 3, 2004, pp. 353-370. doi:10.1111/j.1751-908X.2004.tb00755.x

[16] T. Andersen, "Correction of Common Lead in U-Pb Analyses That Do Not Report ${ }^{204} \mathrm{~Pb}$," Chemical Geology, Vol. 192, No. 1-2, 2002, pp. 59-79. doi:10.1016/S0009-2541(02)00195-X

[17] K. R. Ludwig, "User's Manual for Isoplot/Ex, Version 3.00. A Geochronological Toolkit for Microsoft Excel," Berkeley Geochronology Center Special Publication, Vol. 4, No. 2, 2003, pp. 1-70.

[18] L. Qi, J. Hu and D. C. Grégoire, "Determination of Trace Elements in Granites by Inductively Coupled Plasma Mass Spectrometry," Talanta, Vol. 51, No. 6, 2000, pp. 507-513.

[19] H. E. Huppert and R. S. J. Sparks, "The Generation of Granitic Magmas by Intrusion of Basalt into Continental Crust," Journal of the Petrology, Vol. 29, No. 3, 1998, pp. 599-624.

[20] C. Annen and R. S. J. Sparks, "Effects of Repetitive Emplacement of Basaltic Intrusions on Thermal Evolution and Melt Generation in the Crust," Earth Planetary Science Letters, Vol. 203, No. 3-7, 2002, pp. 937-955.

[21] F. Y. Wu, X. H. Li and J. H. Yang, "Discussions on the Petrogenesis of Granites," Acta Petrologica Sinica, Vol. 23, No. 6, 2007, pp. 1217-1238.

[22] H. F. Ling, W. Z. Shen and P. Deng, “Age, Geochemistry and Petrogenesis of the Sundong Granite, Northern Guangdong Province," Acta Petrologica Sinica, Vol. 20, No. 3, 2004, pp. 413-424.

[23] J. H. Yu, X. M. Zhou and L. Zhao, "Mantle-Crust Interaction Generating the Wuping Granites: Evidence from Sr-Nd-Hf-U-Pb Isotopes," Acta Petrologica Sinica, Vol. 21, No. 3, 2005, pp. 651-664.

[24] J. S. Qiu, J. Hu and B. I. A. McInnes, "Geochronology, Geochemistry and Petrogenesis of the Longwo Granodioritic Pluton in Guangdong Province," Acta Petrologica Sinica, Vol. 20, No. 6, 2004, pp. 1363-1374.

[25] S. Y. Jiang, L. Li, B. Zhu, X. Ding, Y. H. Jiang, L. X. Gu and $\mathrm{P}$. Ni, "Geochemical and Sr-Nd-Hf Isotopic Compositions of Granodiorite from the Wushan Copper Deposit, 
Jiangxi Province and Their Implications for Petrogenesis," Acta Petrologica Sinica, Vol. 24, No. 8, 2008, pp. 1679-1690.

[26] D. J. DePaolo, "Trace Element and Isotopic Effects of Combined Wallrock Assimilation and Fractionation Crystallization," Earth and Planetary Science Letters, Vol. 53, No. 2, 1981, pp. 189-202. doi:10.1016/0012-821X(81)90153-9

[27] C. W. Devey and K. G. Cox, "Relationships between Crustal Contamination and Crystallization in Continental Flood Basalt Magmas with Special Reference to the Deccan Traps of the Western Ghats, India," Earth and Planetary Science Letters, Vol. 84, No. 1, 1987, pp. 59-68. doi:10.1016/0012-821X(87)90176-2

[28] J. S. Marsh, "Geochemical Constraints on Coupled Assimilation and Fractional Crystallization Involving Upper Crustal Compositions and Continental Tholeiitic Magma," Earth Planetary Science Letter, Vol. 92, No. 1, 1989, pp. 78-80. doi:10.1016/0012-821X(89)90021-6

[29] B. Mingram, R. B. Trumbull, S. Littman and H. Gertenberger, "A Petrogenetic Study of Anorogenic Felsic Magmatism in the Cretaceous Paresis Ring Complex, Namibia: Evidence for Mixing of Crust and Mantle-Derived Components," Lithos, Vol. 54, No. 1-2, 2000, pp. 1-22. doi:10.1016/S0024-4937(00)00033-5

[30] P. J. Sylvester, "Post-Collisional Strongly Peraluminous Granites," Lithos, Vol. 45, No. 1-4, 1998, pp. 29-34. doi:10.1016/S0024-4937(98)00024-3

[31] Q. Zhang, Y. Wang and C. D. Li, "Granite Classification on the Basis of $\mathrm{Sr}$ and $\mathrm{Yb}$ Contents and Its Implications," Acta Petrologica Sinica, Vol. 22, No. 9, 2006, pp. 22492269.

[32] X. H. Li, Z. X. Li, W. X. Li, Y. Liu, C Yuan, G. J. Wei and C. S. Qi, "U-Pb Zircon, Geochemical and Sr-Nd-Hf Isotopic Constraints on Age and Origin of Jurassic I and A-Type Granites from Central Guangdong, SE China: A Major Igneous Event in Response to Foundering of a Subducted Flat-Slab," Lithos, Vol. 96, No. 2, 2007, pp. 186-204. doi:10.1016/j.lithos.2006.09.018

[33] E. B. Watson and T. M. Harrison, "Zircon Saturation Revisited: Temperature and Composition Effects in a Va- riety of Crustal Magma Types," Earth and Planetary Science Letters, Vol. 64, No. 2, 1983, pp. 295-304. doi:10.1016/0012-821X(83)90211-X

[34] E. A. K Middlemost, "Naming Materials in the Magma/ Igneous Rock System," Earth-Science Reviews, Vol. 37 , No. 3-4, 1994, pp. 215-224. doi:10.1016/0012-8252(94)90029-9

[35] R. W. Le Maitre, "Igneous Rocks: A Classification and Glossary of Terms," 2nd Edition, Cambridge University Press, Cambridge, 2002.

[36] E. A. K. Middlemost, "A Simple Classification of Volcanic Rocks," Bulletin of Volcanology, Vol. 36, No. 2, 1972 , pp. 382-397. doi:10.1007/BF02596878

[37] S. S. Sun and W. F. McDonough, "Chemical and Isotopic Systematics of Oceanic Basalts: Implications for Mantle Composition and Processes. Magmatism in the Ocean Basins," In: A. D. Saunders and M. J. Norry, Eds., Geological Society Special Publication, London, 1989, pp. 313-345.

[38] Y. M. Wang, Y. S. Gao, H. M. Han and X. H. Wang, "Practical Handbook of Reference Materials for Geoanalysis," Geological Publishing House, Beijing, 2003.

[39] M. Thompson, P. J. Potts, J. S. Kane and S. Wilson, “An International Proficiency Test for Analytical Geochemistry Laboratories-Report on Round 5 (August 1999)," Geostandards and Geoanalytical Research, Vol. 24, No. 1, 2000, pp. E1-E28.

[40] P. J. Potts and J. S. Kane, "International Association of Geoanalysts Certificate of Analysis: Certified Reference Material OU-6 (Penrhyn Slate)," Geostandards and Geoanalytical Research, Vol. 29, No. 2, 2005, pp. 233-236. doi:10.1111/j.1751-908X.2005.tb00895.x

[41] R. H. Steiger and E. Jäger, "Subcommission on Geochronology; Convention on the Use of Decay Constants in Geochronology and Cosmochronology," Earth and Planetary Science Letters, Vol. 36, No. 3, 1977, pp. 359-362.

[42] G. W. Lugmair and K. Harti, "Lunar Initial ${ }^{143} \mathrm{Nd} /{ }^{144} \mathrm{Nd}$ : Differential Evolution of the Lunar Crust and Mantle," Earth and Planetary Science Letters, Vol. 39, No. 3, 1978, pp. 349-357. doi:10.1016/0012-821X(78)90021-3 